\title{
Floral Changes Following Mechanical Brush Removal in Central Texas
}

\author{
DALE ROLLINS AND FRED C. BRYANT
}

\section{Abstract}

A field study was initiated in May 1981 to monitor the effectiveness of mechanical brush control (chaining) as a method of reclaiming Ashe juniper (Juniperus asheit)-oak (Quercus spp.) dominated rangelands in central Texas. Brush was cleared from 4 sites by double-chaining and the resultant slash was burned. Brush canopy reduction and herbaceous standing crop were monitored for 2 growing seasons following treatment. Total brush canopy at 1 year post-treatment was $\mathbf{8 0 \%}$ less than untreated brush stands. Chaining was more effective for Ashe juniper ( $93 \%$ reduction) than for oaks (64-75\% reduction). Grass and forb standing crop at 22 months post-treatment was $55 \%$ higher on chained sites during all collection months.

The Edwards Plateau, a 10 million-ha resource area located in west central Texas, is noted for domestic sheep and goat production and the densest herd of white-tailed deer (Odocoileus virginianus) in North America. Over the last century, the Edwards Plateau has retrogressed from Mixed Prairie to a scrub oak-juniper disclimax (Buechner 1944). Reasons for the increased densities of woody species, primarily Ashe juniper (Juniperus asheii), plateau live oak (Quercus virginiana var. fusiformis), and Vasey shinoak (Q. pungens var. vaseyanna), include fire suppression, livestock overgrazing, seed dispersal by herbivores, and/or a shift in climate (Buechner 1944, Johnsen 1962).

Brush overstory and herbaceous forage production are related inversely (Scifres et al. 1976). Smith and Rechenthin (1964) stated that about $50 \%$ of the Edwards Plateau supported sufficient brush canopy to seriously suppress herbaceous forage production for livestock. The primary goal of brush management is to replace noxious brush species with productive and palatable forages (Mutz et al. 1978). Brush treatments using chemical or mechanical methods usually result in improved herbaceous forage production (Waldrip 1954, Vallentine 1960, Clary 1974, Scifres et al. 1976, Mutz et al. 1978, Clary and Jameson 1981). Vallentine (1960) reported that areas cleared of Ashe juniper by handcutting produced over 6 times more forage than uncleared areas.

Because of the general ineffectiveness of herbicides on junipers (Scifres 1980), chaining is usually the method of choice for reclaiming juniper-infested rangelands. It is particularly effective for single-stemmed, nonsprouting species like Ashe juniper. Chaining operations often result in variable effects, both in terms of brush kill and forage response (Aro 1971). Because of the economic significance of wildlife to ranchers in Texas, information on cover changes and subsequent forage production is necessary for the proper multiple-use management of these brushlands. This study was initiated in May 1981 to document overstory-understory relationships following a chaining operation aimed at improving habitat for white-tailed deer.

\section{Study Area and Methods}

This study was conducted on the 20,000-ha Y O Ranch located in northwestern Kerr County, Texas. Soils of this area are predomi-

\footnotetext{
Authors are extension range specialist, Agronomy Department, Oklahoma State University, Stillwater 74078; and associate professor, Department of Range and Wild life Management, Texas Tech University, Lubbock 79409. At the time of the research, the senior author was graduate research assistant, Department of Range and Wildlife Management, Texas Tech University.

Funding was provided by the Noxious Brush and Weed Control Program at Texas Tech. We acknowledge Mr. Charles S. Schreiner IV for allowing this research to be conducted on his ranch and Mr. Doug D. Waid for providing field assistance.
}

nantly Tarrant stoney clays (Lithic Calciustolls) with limestone rocks as a common surface feature. Soils are shallow $(<25 \mathrm{~cm})$ and overlie a lithic limestone contact. About $85 \%$ of the study area is a Low Stoney Hill range site. Climate is characterized as subhumid with hot summers and mild winters. The average frost-free period is 220 days ( 1 April to 10 November). Average annual precipitation recorded at Junction, Texas, (30 km north of study area) is $64 \mathrm{~cm}$ with bimodal peaks in May and September (Fig. 1). Much of the

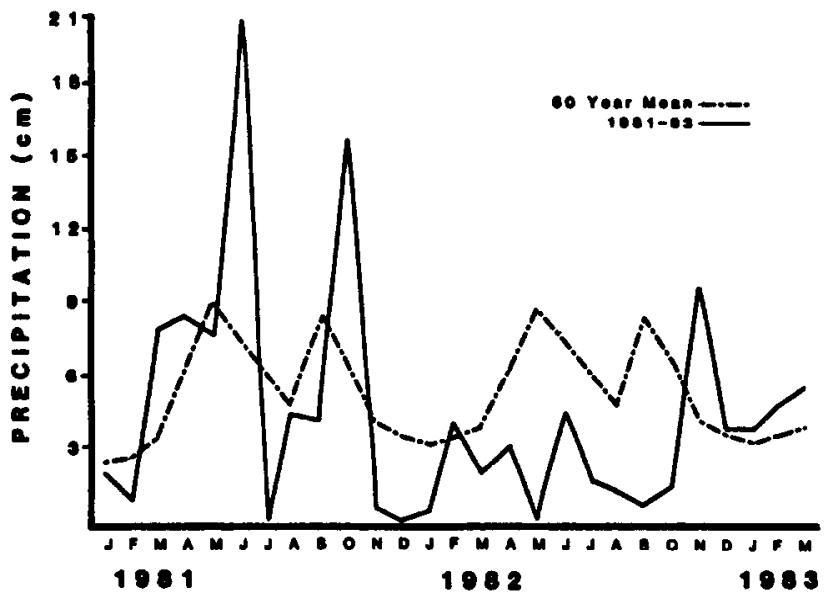

Fig. 1. Monthly precipitation totals (cm) and long-term average precipitation recorded at Junction, Texas, 1981-83.

annual rainfall results from high intensity thunderstorms with much water lost as runoff. Summer droughts are common.

The study area was typical of the Edwards Plateau and was dominated by Ashe juniper, plateau live oak, and Vasey shinoak. Common woody species included algerita (Berberis trifoliata), mesquite (Prosopis glandulosa), sugar hackberry (Celtis laevigata), and Texas persimmon (Diospyros texanus). Common grasses included common curlymesquite (Hilaria belangeri), Wright threeawn (Aristida wrightii), hairy tridens (Erioneuron pilosum), Texas wintergrass (Stipa leucotricha), and grama grasses (Bouteloua spp.). Forb production and diversity vary with soil depths, precipitation, and grazing pressure (Smeins et al. 1976, Bryant et al. 1981).

Four pastures (400-1,380 ha) were selected based on similarity of brush cover, especially Ashe juniper. Brush canopy cover before treatment ranged from 20-60\% with Ashe juniper accounting for about half of the total canopy. Age structure of the juniper stands appeared similar except in Elm pasture where some chaining had occurred in 1964 resulting in a greater proportion of younger junipers. Areas were double-chained from May-June 1981 in a systematic pattern of 8-ha openings to enhance wildlife use of clearings. The unmodified chain weighed $38 \mathrm{~kg} /$ link and was $85 \mathrm{~m}$ in length. Two crawler tractors pulled the chain in a $U$-shaped fashion at a speed of 4-6 km/ hr. The resulting slash piles were burned in July 1981 under the following prescription: winds $<15$ $\mathrm{km} / \mathrm{hr}$, relative humidity $>40 \%$, and air temperatures of $24-29^{\circ} \mathrm{C}$.

Livestock operations in the past included cattle, sheep, and both Angora and Spanish goats. White-tailed deer densities averaged 1 deer $/ 5$ ha with lesser numbers of several species of exotic ungulates. Most pastures on the ranch have been grazed continuously, 
yearlong with some combination of cattle, sheep, and goats. Grazing histories of the study pastures prior to 1978 were unavailable, but from 1978-80 Angora goats and cattle were stocked yearlong in Elm and West North Home (WNH) pastures at about 12 ha/ AU. Corner pasture had been stocked with sheep at about 14 ha/AU while Rocky pasture was stocked with cattle, sheep, and Spanish goats at 10 ha/AU. Study pastures were rested from livestock grazing beginning January 1981, prior to brush removal, and through the duration of the study (March 1983).

Measurements of canopy cover at 1 year post-treatment were obtained for Ashe juniper, live oak, and shinoak in June 1982 using a line intercept technique (Canfield 1941). Two, 30.5-m line transects, oriented at right angles to each other, were read from 10-15 randomly located points on both cleared areas and adjoining brushlands within each pasture. Canopy reduction was computed as the difference in canopies between clearings and adjoining brushlands. Canopy data were analyzed using unpaired $t$-tests with significance noted at the 0.05 level.

Herbage weight, by species, was estimated using the foliar estimation technique described by Anderson and Kothmann (1982). Representative samples of grass and forb species were clipped and air-dried to a constant weight to obtain weight/foliar unit estimates. On each of 2 clearings, foliar cover data were recorded on $20,0.25-\mathrm{m}$ square quadrats per clearing for a total of $\mathbf{4 0}$ quadrats per pasture. Twenty quadrats were read from adjacent brushlands. Herbage biomass was monitored at 5, 8, 12, 15, 19, and 22 months post-treatment. Data were analyzed with analysis of variance using a split-plot in time design (Steel and Torrie 1960) with pastures serving as blocks.

Grass data for Elm pasture were not included in the analyses because of the introduction of cattle in May 1982. While the stocking rate for the entire pasture (1,300 ha) was considered light ( 55 ha/AUY), direct observation revealed that cattle preferentially foraged on cleared areas. Waldrip (1954) reported similar cattle behavior on burned and cleared areas after juniper removal. Thus, we believed this differential use by cattle of cleared versus brush areas negatively biased the grass data on chained sites in Elm pasture. For the same reason, data for Corner pasture collected in March 1983 were omitted from the analyses.

\section{Results and Discussion}

\section{Overstory Reduction}

Double chaining and slash burning reduced total brush canopy an average of $81 \%$ as compared to untreated sites $(P<0.01)$ (Table 1). Ashe juniper was reduced by $93 \%$ (range 81-96). High posttreatment canopy cover reduction was attributed to restricted root depths and excellent soil moisture conditions during chaining. Generally, junipers less than $1.5 \mathrm{~m}$ in height were not uprooted by chaining, probably because of their high stem flexibility (Arnold et al. 1964, Aro 1971). Indeed, lowest juniper reduction (81\%) was observed in Rocky pasture where many smaller $(<1.5 \mathrm{~m}$ ) junipers were present. Most junipers greater than $5 \mathrm{~m}$ tall were uprooted by the first pass of the chain.

Vasey shinoak was reduced by $64 \%$ (range $31-85$ ) whereas liveoak decreased by $75 \%$ (range 41-93). Both species resprout readily following overstory removal (Vallentine 1960), thus most of the Quercus encountered on clearings was less than $0.5 \mathrm{~m}$ in height. Unlike junipers, oaks tended to break off at ground level rather than be uprooted. Oak stems were apparently more brittle than those of Ashe junipers, as chaining knocked down the majority of oaks greater than $0.5 \mathrm{~m}$ tall.

Quercus resprouts, primarily $Q$. pungens, were an important forage for white-tailed deer during the period of this study (Waid et al. 1984). Also, deer kept $Q$. virginiana resprouts on cleared areas browsed to ground level year-round. If such frequent and severe defoliations occur for several consecutive years, oak mortality on cleared areas could become substantial (Buechner 1944, Merrill 1975, Davis et al. 1975). Because resprouts are nutritious browse when actively growing, with crude protein values of $13-17 \%$ (Huston et al. 1981), their elimination would be undesirable for deer and goat production.

Table 1. Canopy cover (\%) of Ashe juniper, Vasey shinoak, and live oak on chained veraus control areas at 4 sites on the Y $O$ Ranch, Kerr County, Texas, June 1982. Chaining was conducted from May-June 1981.

\begin{tabular}{|c|c|c|c|c|c|c|c|c|}
\hline \multirow[b]{2}{*}{ Pasture } & \multicolumn{2}{|c|}{ Juniper } & \multicolumn{2}{|c|}{ Shinoak } & \multicolumn{2}{|c|}{ Liveoak } & \multicolumn{2}{|c|}{ Total $^{*}$} \\
\hline & Chained & Control & Chained & Control & Chained & Control & Chained & Control \\
\hline Elm & $0.4^{* *}$ & 10.5 & 1.5 & 2.1 & 0.6 & 1.3 & $2.6^{* *}$ & 14.8 \\
\hline WNH & $1.1 *$ & 21.5 & 6.9 & 13.2 & 0.3 & 4.1 & $8.2^{*}$ & 40.1 \\
\hline Corner & $1.3^{*}$ & 23.9 & $4.3^{*}$ & 28.6 & 1.3 & 3.5 & $6.9^{* *}$ & 56.9 \\
\hline Rocky & $4.0^{*}$ & 20.9 & 6.9 & 11.1 & 1.9 & 3.2 & $10.8^{*}$ & 38.6 \\
\hline MEANS & $1.7 *$ & 19.2 & 4.9 & 13.8 & 0.8 & 3.2 & $7.1^{* *}$ & 37.6 \\
\hline
\end{tabular}

"Includes 5 other species (Berberis trifoliata, Bumelia lanuginosa, Celtis laevigata, Diospyros texanus, Prosopis glandulosa).

*Figures for chained areas followed by an asterisk(s) are significantly different from control aras at the $5 \%(*)$ or $1 \%(* *)$ level.

Table 2. Mean grass biomass (kg/ha) at 4 sites, 6 to 22 months following overstory removal on the Y O Ranch, Kerr County, Texas, 1981-83. Areas were chained from May-June 1981.

\begin{tabular}{|c|c|c|c|c|c|c|c|c|c|c|}
\hline & \multicolumn{8}{|c|}{ Pasture } & & \\
\hline & \multicolumn{2}{|c|}{ Elm } & \multicolumn{2}{|c|}{ WNH } & \multicolumn{2}{|c|}{ Corner } & \multicolumn{2}{|c|}{ Rocky } & \multicolumn{2}{|c|}{ Date mean } \\
\hline & Chained & Control & Chained & Control & Chained & Control & Chained & Control & Chained & Control \\
\hline November 1981 & 110 & 180 & 260 & 400 & 620 & 530 & 290 & 220 & 320 & 280 \\
\hline March 1982 & 150 & 250 & $120^{*}$ & 250 & 400 & 530 & 260 & 280 & $230^{*}$ & 330 \\
\hline May 1982 & - & - & 650 & 590 & 800 & 940 & 400 & 360 & 620 & 630 \\
\hline August 1982 & - & - & $1,200^{*}$ & 570 & 1,150 & 1,050 & $1,390 * *$ & 380 & $1,250^{*}$ & 660 \\
\hline December 1982 & - & - & 490 & 470 & $850^{*}$ & 230 & 240 & $660^{\circ}$ & 310 & 310 \\
\hline March 1983 & - & - & 760 & 470 & - & - & $950 * *$ & 180 & $860^{*}$ & 330 \\
\hline Pasture mean & 130 & 210 & 580 & 460 & 770 & 650 & $660^{* *}$ & 280 & $660^{*}$ & 420 \\
\hline
\end{tabular}

** Means within a pasture separated by an asterisk(s) are significantly different at the $5 \%\left({ }^{*}\right)$ or $1 \%(* *)$ level.

"Data excluded from analyses due to the introduction of cattle into pasture. 
Table 3. Mean forb biomass (kg/ha) at 4 sites, 6 to 22 months following overstory removal on the Y O Ranch, Kerr County, Texas, 1981-83. Areas were chained from May-June 1981.

\begin{tabular}{|c|c|c|c|c|c|c|c|c|c|c|}
\hline & \multicolumn{8}{|c|}{ Pasture } & & \\
\hline & \multicolumn{2}{|c|}{ Elm } & \multicolumn{2}{|c|}{ WNH } & \multicolumn{2}{|c|}{ Corner } & \multicolumn{2}{|c|}{ Rocky } & \multicolumn{2}{|c|}{ Date mean } \\
\hline & Chained & Control & Chained & Control & Chained & Control & Chained & Control & Chained & Control \\
\hline November 1981 & 70 & 140 & 50 & 20 & 20 & 40 & $50^{*}$ & 20 & 50 & 60 \\
\hline March 1982 & 50 & 30 & $90^{* *}$ & 0 & $140 * *$ & 10 & 110 & 100 & $100^{*}$ & 40 \\
\hline May 1982 & 80 & 110 & 130 & 120 & 180 & 160 & 140 & 120 & 140 & 130 \\
\hline August 1982 & $70^{*}$ & 20 & $60^{*}$ & 10 & 20 & 40 & $140 * *$ & 20 & $70^{*}$ & 20 \\
\hline December 1982 & 10 & 10 & $20^{*}$ & 0 & 0 & 0 & $40 * *$ & 10 & 20 & 0 \\
\hline March 1983 & 80 & 50 & 70 & 60 & $120^{*}$ & 60 & $130^{* *}$ & 40 & $100^{*}$ & 50 \\
\hline Pasture mean & 60 & 60 & $70^{*}$ & 40 & 80 & 50 & $100^{*}$ & 50 & 80 & 50 \\
\hline
\end{tabular}

** Means within a pasture separated by an asterisk(s) are significantly different at the $5 \%(*)$ or $1 \%\left({ }^{* *}\right)$ level.

\section{Forage Response}

Herbage increased an average of $55 \%$ following overstory removal (Tables 2 and 3). Grass standing crop (GSC) averaged over the first 22 months post-treatment was higher $(R<0.05)$ on chained areas ( $\bar{x}=660 \mathrm{~kg} / \mathrm{ha}$ ) (Table 2). On chained areas, GSC ranged from $230 \mathrm{~kg} / \mathrm{ha}$ in March 1982 to $1,250 \mathrm{~kg} / \mathrm{ha}$ in August 1982. On untreated areas, GSC varied from $280 \mathrm{~kg} /$ ha in November 1981 to $660 \mathrm{~kg} / \mathrm{ha}$ in August 1982. The date $X$ treatment interaction was significant $(P<0.05)$. Grass standing crop was varied between pastures $(P<0.05)$; however the pasture $\times$ treatment interaction was not significant $(P>0.05)$.

Most grass species (and Carex) showed nonsignificant increases following overstory removal. The only species that increased significantly $(P<0.05)$ following chaining were Wright threeawn, hairy tridens, and red grama (B. trifida), none of which are desirable forage species for cattle or sheep. Such desirable decreasers as little bluestem (Schizachyrium scoparium), indiangrass (Sorghastrum nutans), and Texas cupgrass (Eriochloa sericea) were not affected $(P<0.05)$ by chaining, at least during the period of the study. These species often are encountered only within the protective shroud of brush thickets that serve as refugia from livestock grazing. After overstory removal, such species respond slowly (Waldrip 1954) and require careful post-treatment grazing management to ensure their continued presence in the grass community (Waldrip 1954, Vallentine 1960). Texas wintergrass, the major cool-season forage species, almost doubled on chained sites. In addition to being an important forage for livestock (Vallentine 1960, Bryant et al. 1979), Texas wintergrass is one of the few grasses used readily by white-tailed deer (Bryant et al. 1981, Waid et al. 1984).

Forb standing crop (FSC) (Table 3) and diversity (Fig. 2) were FORB DIVERSITY

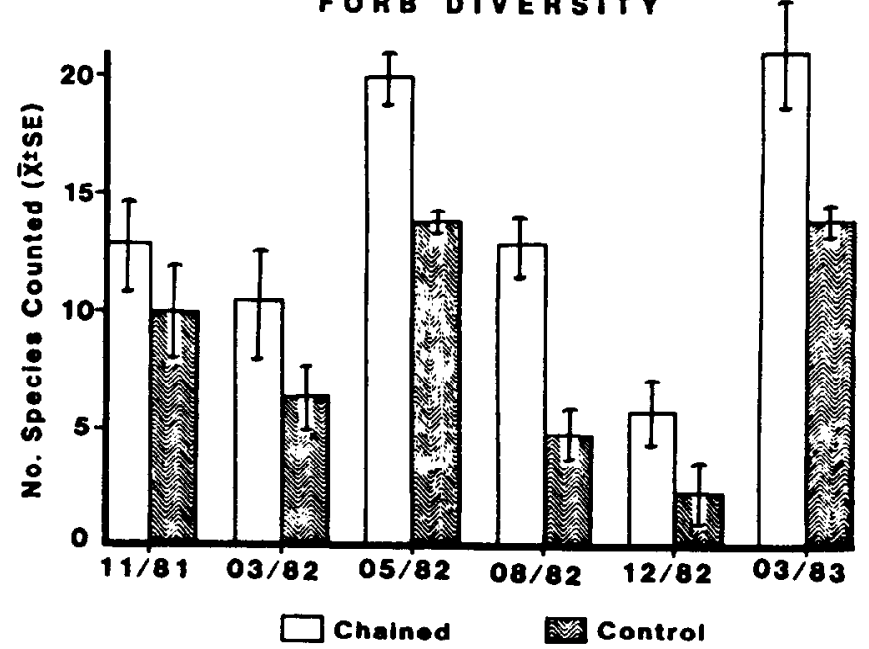

Fig. 2. Forb diversity (number of species encountered) on chained versus control sites on the YO Ranch, Kerr County, Texas, 1981-83. highly variable between sampling dates because of seasonal fluctuations in precipitation (Fig. 1). Forb standing crop was different among dates $(P<0.05)$; however, the date $\times$ treatment interaction was not significant $(P>0.05)$. After 5 months post-treatment, FSC tended to be greater on chained sites. On chained sites, FSC was higher $(P<0.05)$ during March and August 1982, and March 1983. These significant differences were largely because of the increased production on clearings of annual forbs like Pennsylvania pellitory (Parietaria pennsylvanica), plantains (Plantago spp.), and bighead evax (Evax prolifera). The benefits of clearing for forb production became especially apparent from April-December 1982 during drought conditions, when FSC was 500 to $600 \%$ greater on cleared sites. This difference was noted even under heavy grazing pressure ( $3 \mathrm{ha} /$ deer) by white-tailed deer and several species of exotic ungulates (Rollins 1983). These herbivores concentrated foraging activities on cleared areas, undoubtedly in response to improved forage conditions.

Availability of forbs on unchained sites was similar among pastures (Table 3). Forb production on chained sites was somewhat higher in Rocky pasture; however, the pasture $X$ treatment interaction was not significant $(P<0.05)$. Species composition of the forb component varied among pastures, presumably because of differences in soil surface texture and depth (Smeins et al. 1976). Areas with deeper soils and fewer surface rocks, e.g., Corner pasture, tended to have lower forb diversity than areas with shallower, rockier soils like those found in Rocky pasture. Upright prairie coneflower (Ratibida columnaris), Pennsylvania pellitory, bighead evax, and spreading sida (Sida filicadulis) were more common on shallower soils, while low wildmercury (Argythamnia humilis), mat euphorbia (Euphorbia sp.), and orange zexmenia (Zexmenia hispida) appeared to be more common on deeper sites.

Across all pastures, forb diversity was highest in March 1983, when an average of 21 species were recorded on chained sites, and lowest in December 1982, when an average of only 2 species were found on unchained sites (Fig. 2). Annual forbs showed the most dramatic responses to chaining. Annuals like prostrate pigweed, one-seeded croton (Croton monanthogynus), low wildmercury, and plantains were 3 to 8 times more common on chained sites than on untreated brushlands. These forbs, plus others like Gordon's bladderpod (Lesquerella gordoni), spreading sida, and mat euphorbia, all of which increased following chaining, are important in the diets of sheep and goats (Bryant et al. 1979), and also white-tailed deer (Bryant et al. 1981, Warren and Krysl 1983, Waid et al. 1984). While most perennial forbs, such as coneflower, verbenas (Verbena spp.), hedyotis (Hedyotis sp.), and Drummond's skullcap (Hedeoma drummondi) tended to increase following chaining, the change was small relative to that of annual forbs.

Some forb species were restricted almost exclusively to cleared areas. Pennsylvania pellitory was found only under juniper skeletons and/or litter accumulations on cleared areas. Prostrate pigweed, one-seeded croton, and low wildmercury were the predominant forbs growing on the areas where brushpiles had burned, but 
were observed infrequently outside treated areas.

Moisture conditions during the study were characterized by above average precipitation during 1981 followed by drought conditions in 1982 (Fig. 1). Such extremes are not uncommon for this area. The above-a verage soil moisture conditions at the time of the chaining probably contributed to the high degree of canopy reduction observed. Likewise, production of annual forbs was facilitated by good moisture conditions. The greatest differences in grass and forb standing crops on chained versus unchained sites were observed during the drier sampling dates, however, suggesting that forage responses following chaining were especially pronounced during drought conditions.

\section{Management Implications}

Double chaining is an effective means of opening up dense stands of Ashe juniper, live oak, and shinoak in the Edwards Plateau. Clearing brush improved livestock movements, wildlife visibility to hunters, and forage availability for domestic and wild herbivores. Data from this study indicated that double-chained and slash-burned areas experienced an overstory reduction of $80 \%$ at 1 year post-treatment with subsequent increases in grass and forb biomass of about $55 \%$ across the study period ( 22 months).

Information on the longevity of mechanical brush treatments for this habitat, both in terms of forage release and brush regrowth, is lacking. Based on our experience in this area, we believe that benefits from brush clearing will be visible for at least 10 years, possibly longer if a prescribed burning program is instituted. Secondary brush problems on cleared areas are primarily small junipers and Texas persimmon. Because of the intense browsing pressure by goats and deer, oak regrowth does not present a major problem. Forb production, especially annuals, probably will decline from the levels observed 1-2 years post-treatment, but should remain above that from untreated brushlands for 5-10 years.

Grass production will increase after overstory removal, but proper post-treatment grazing management is paramount for maintaining decreaser species. Vallentine (1980) suggested treating only sites with deep fertile soils to obtain maximum forage dividends from brush treatments. Whereas grass production in this study appeared to be greatest on sites with deeper soils, forb production and diversity were greatest on rocky, shallow sites. Thus, there may be a trade-off in species and/or classes between sites. If so, managers could manipulate the kinds of animals best adapted to a particular site, e.g. goats, sheep, and/or deer on rocky sites, with deer and/or cattle on deeper soils.

Chaining costs for this study averaged $\$ 36 /$ ha while costs for slash burning were estimated at $\$ 4 /$ ha. In brush stands dominated by virgin Ashe junipers, single chaining might have produced similar results at a lower cost/ha than double chaining, but in mixed stands of junipers and oaks of different age/size classes, double chaining was probably most cost-effective. The windrowing effect of double chaining not only increased brush kill, but also facilitated slash burning.

Preferably, some brush cover should be spared to allow continued use of chained areas by white-tailed deer. Juniper and oak cover is important for both food and cover, thus brush eradication is not only infeasible, but also is unsound. Recent studies suggested preferential foraging use of certain Ashe junipers by white-tailed deer (Bryant, unpubl. data, Rollins, unpubl. data). If these preferred trees could be identified and marked, they could be spared from brush clearing operations. Such selective clearing might allow managers to tailor brush management operations so that more brush could be removed for livestock operations while maintaining suitable habitat for deer. Such a scheme should allow ranchers on the Edwards Plateau to increase profits from livestock and wildlife operations.
Finally, chaining often results in a drastic change in the landscape. Whereas large expanses devoid of woody vegetation may be appealing to some ranchers, most user groups view such a scene aesthetically displeasing. Therefore, chaining operations should incorporate applied landscape techniques (Williamson and Currier 1971) to lessen the abrupt changes between treated and untreated areas. Such techniques not only create a more pleasing aspect, but also enhance wildlife use of treated areas.

\section{Literature Cited}

Anderson, D.M., and M.M. Kothmann. 1982. A two-step sampling technique for estimating standing crop of herbaceous vegetation. J. Range Manage. 35:675-677.

Arnold, J.R., D.A. Jameson, and E.H. Reid. 1964. The pinyon-juniper type of Arizona: effects of grazing, fire, and tree control. U.S.D.A., Agr. Res. Serv. Production Res. Rep. 84.

Aro, R.S. 1971. Evaluation of pinyon-juniper conversion to grassland. J. Range Manage. 24:188-197.

Bryant, F.C., M.M. Kothmann, and L.B. Merrill. 1979. Diets of sheep, Angora goats, Spanish goats, and white-tailed deer under excellent range conditions. J. Range Manage. 32:412-417.

Bryant, F.C., C.A. Taylor, and L.B. Merrill. 1981. White-tailed deer diets from pastures in excellent and poor range condition. J. Range Manage. 34:193-200.

Buechner, H.K. 1944. The range vegetation of Kerr County, Texas, in relation to livestock and white-tailed deer. Amer. Midl. Nat. 31:697-743.

Canfield, R.H. 1941. Application of the line interception method in sampling range vegetation. J. For. 39:388-394.

Clary, W.P.1974. Response of herbaceous vegetation to felling of alligat or juniper. J. Range Manage. 27:387-389.

Clary, W.P., and D.A. Jameson. 1981. Herbage production following tree and shrub removal in the pinyon-juniper type of Arizona. J. Range Manage. 34:109-113.

Davis, G.G., L.E. Bartel, and C.W. Cook. 1975. Control of Gambel oak sprouts by goats. J. Range Manage. 28:216-218.

Huston, J.E., B.S. Rector, L.B. Merrill, and B.S. Engdahl. 1981. Nutritional value of range plants in the Edwards Plateau region of Texas. Texas Agr. Exp. Sta. Rep. B-1357.

Johnsen, T.N., Jr. 1962. One-seeded juniper invasion of northern Arizona. Ecol. Monogr. 32:187-207.

Merrill, L.B. 1975. The role of goats in biological control of brush. Beef Cattle Sci. Handbook 12:372-376.

Mutz, J.L., C.J. Scifres, D.L. Drawe, T.W. Box, and R.E. Whitson. 1978. Range vegetation after mechanical brush treatment on the coastal prairie. Texas Agr. Exp. Sta. Bull. 1191.

Rollins, D. 1983. Wildlife response to different intensities of brush removal on the Edwards Plateau of Texas. Ph.D. Thesis, Texas Tech Univ. Microfilms, Ann Arbor, Mich. (Diss. Abstr. Int. 44:2299).

Scifres, C.J. 1980. Brush management - principles and practices for Texas and the Southwest. Texas A\&M Univ. Press, College Station.

Scifres, C.J., J.L. Mutz, and G.P. Durham. 1976. Range improvement following chaining of south Texas mixed brush. J. Range Manage. 29:418-421.

Smeins, F.E., T.W. Taylor, and L.B. Merrill. 1976. Vegetation of a 25-year exclosure on the Edwards Plateau of Texas. J. Range Manage. 29:24-29.

Smith, A.C., and C.A. Rechenthin. 1964. Grassland restoration, Part I, the Texas brush problem. U.S.D.A. Soil Cons. Serv., Temple, Texas.

Steel, R.G.D., and J.H. Torrie. 1980. Principles and procedures of statistics. Second edition. McGraw-Hill, New York.

Vallentine, J.F. 1960. Live oak and shin oak as desirable plants on Edwards Plateau ranges. Ecology 41:545-548.

Vallentine, J.F. 1980. Range development and improvements. 2nd Ed. Brigham Young Univ. Press, Provo, Utah.

Wald, D.D., R.J. Warren, and D. Rollins. 1984. Seasonal deer diets in central Texas and their response to brush control. Southwest Nat. 29:301-307.

Waldrip, W.J. 1954. Brush control, grazing management, and revegetation of areas infested with blueberry cedar. Texas Agr. Exp. Sta. Rep. 1721.

Warren, R.J., and L.J. Krysl. 1983. White-tailed deer food habits and nutritional status as affected by grazing and deer-harvest management. J. Range Manage. 36:104-109.

Williamson, R.M., and W.F. Currier. 1971. Applied landscape management in plant control. J. Range Manage. 24:2-6. 